\title{
Susceptibility of Brachyspira hyodysenteriae Isolates to Doxycycline using Agar Dilution and Epsilometer Test
}

\author{
D. LOBOVÁ, A. ČÍŽEK \\ Department of Microbiology and Immunology, Division of Pathobiology \\ Faculty of Veterinary Medicine \\ University of Veterinary and Pharmaceutical Sciences, Brno \\ Received February 6, 2004 \\ Accepted July 29, 2004
}

\section{Abstract}

Lobová D., A. Čížek: Susceptibility of Brachyspira hyodysenteriae Isolates to Doxycycline using Agar Dilution and Epsilometer Test. Acta Vet. Brno 2004, 73: 329-333.

The agar dilution method and the Epsilometer test were used to evaluate antibacterial susceptibility of 49 Brachyspira hyodysenteriae field isolates to doxycycline. A comparison of results obtained by the two methods revealed agreement for $84 \%$ of $B$. hyodysenteriae isolates; with $16 \%$ of isolates the Minimal Inhibitory Concentration values differing by two and more dilutions. Out of the total of $B$. hyodysenteriae isolates tested, $36(73 \%)$ were classified as sensitive, $13(27 \%)$ as intermediary, and none of the strains were found doxycycline-resistant. The demonstrated susceptibility of $B$. hyodysenteriae isolates to doxycycline suggests the possibility of using it for combination therapy with pleuromutilins of swine dysentery. The Epsilometer test has proved a practical alternative to dilution methods of $B$. hyodysenteriae susceptibility testing.

Etest, swine dysentery, Minimum Inhibitory Concentration, antibiotics

The number of farms infected with a clinical form of swine dysentery in the Czech Republic has grown significantly in recent years (Čížek et al. 2003). The causal agent of the disease is Brachyspira hyodysenteriae, an intestinal spirochete, causing serious mucosal haemorrhagic scouring, especially in fattening pigs (Harris et al. 1972). Economic loss in swine herds attacked with dysentery can be reduced by treating clinically ill pigs and prescribing preventive medication of feed to categories of swine that are at risk. In recent years, there have been increased reports of reduced clinical efficacy of first choice antibiotics in the Czech Republic (Čížek et al. 2002) as well as abroad (Molnár 1996; Karlsson et al. 2002). For this reason the appropriate choice of antibiotics for therapy is very important and should be made on the basis of laboratory test results whenever possible. The laboratory methods available are currently being standardized (Karlss on et al. 2002). There is also a need for new simple testing alternatives to complement the existing methods, which are rather demanding in terms of both time and material, such as the agar dilution method (ADM) and the broth dilution method (BDM). One such method could be the Epsilometer test (Etest), which has been used for susceptibility testing of anaerobic bacteria (Rosenblatt and Gustafson 1995) in human medicine. This trial focused on testing susceptibility of $B$. hyodysenteriae strains to doxycycline (tetracycline group of antimicrobial agents) using the Etest and the agar dilution method. The results achieved by the two methods were compared and the appropriateness of the Etest for B. hyodysenteriae susceptibility testing was assessed.

Materials and Methods

Bacterial cultures

The trial used 49 field isolates of $B$. hyodysenteriae isolated from clinical cases of dysentery in swine herds in the Czech Republic from 1999 to 2001 . The strain B. hyodysenteriae ATCC $27164^{\mathrm{T}}$ was used as a reference culture.

Address for correspondence:

MVDr. Dana Lobová

Department of Microbiology and Immunology

University of Veterinary and Pharmaceutical Sciences

Palackého 1-3, 61242 Brno, Czech Republic
Phone: +402541562 290

Cell phone: +4206067045444

e-mail: lobovad@vfu.cz

http://www.vfu.cz/acta-vet/actavet.htm 
B. hyodysenteriae isolates were verified using strong beta haemolysis, biochemical testing (Fellström and Gunnarss on 1995) and PCR (E1der et al. 1994). Brachyspira isolates were stored in a cryopreservation medium at $-80^{\circ} \mathrm{C}$. Before test for resistance, the isolates were cultivated on Wilkins-Chalgren anaerobic agar (Oxoid) and strain purity was microscopically verified after cultivation in an anaerostat for 3 days at $37^{\circ} \mathrm{C}$. Microbiological checks of the cultures were made using culture smears stained with $1 \%$ crystal violet solution.

The agar dilution method

Doxycycline MIC (Minimal Inhibitory Concentration) values were determined using the agar dilution method applied on Wilkins-Chalgren anaerobic agar supplemented with 5\% of defibrinated sheep blood. The 3-day culture was suspended in tryptose soya broth (BBL) up to $1^{\circ}$ turbidity level on the McFarland turbidity scale. A suspension was prepared as a 1/100 dilution in sterile deionised water for final concentration $10^{6} \mathrm{CFU} / \mathrm{ml}$ according the NCCLS methods for anaerobic bacteria (M11 A5, 2001). Subsequently, $20 \mu 1$ of suspension of each isolate were inoculated to the surface of the agar containing $0.06 ; 0.125 ; 0.25 ; 0.5 ; 1 ; 2 ; 4 ; 8 ; 16 ; 32 \mu \mathrm{g} / \mathrm{ml}$ of doxycycline hyclate (Rhône Mérieux) in a rosette-like pattern and simultaneously to doxycycline hyclate-free agar. The inoculated plates were incubated anaerobically in the gas generating kit (BR38, Oxoid) for 3-4 days at $37{ }^{\circ} \mathrm{C}$. The lowest concentration of the antibiotic preventing hemolytic activity and growth of the strain tested was recorded as MIC. The reference strain was Brachyspira hyodysenteriae -B78-ATCC $27164^{\mathrm{T}}$.

\section{The Etest}

Simultaneously with the ADM, the Etest (AB Biodisk) was used in accordance with the manufacturer's instructions. Suspensions of cultures prepared in the same way as with the ADM method were diluted with saline solution to produce a final concentration corresponding to $0,5-1^{\circ}$ on the McFarland turbidity standard. Wilkins-Chalgren anaerobic agar was inoculated with $2 \mathrm{ml}$ of this bacterial suspension covering the whole agar surface. Immediately after removing the surplus suspension by using sterile pipette and leaving it to set about ten minutes, individual doxycycline strips (with concentration gradient $256-0.016 \mu \mathrm{g} / \mathrm{ml}$ ) were applied to dry individual plates. The plates were placed in an anaerostat and incubated anaerobically for 3 days at $37^{\circ} \mathrm{C}$. With the field isolates, a reference strain of B. hyodysenteriae ATCC $27164^{\mathrm{T}}$ was tested as a control. In the comparison of MIC values produced by the two methods, the differences of two or more dilutions were regarded as disagreement.

The MIC values obtained by the two methods were documented in Microsoft Excel and compared using 3 interpretation categories of susceptibility of anaerobic bacteria to tetracycline according to NCCLS M11-A5 (2001).

\section{Results}

MIC values for doxycycline obtained by the ADM and the Etest are stated in Table 1. Of the total of 49 B. hyodysenteriae field isolates tested by the ADM $36(73 \%)$ were sensitive, $13(27 \%)$ were intermediary and none were found to be doxycycline-resistant. The Etest MIC values differed for 8 isolates (16\%). From these eight different isolates was sensitivity of four isolates proved by the ADM and the Etest, but four isolates were due to the differences in their MIC values influenced in the interpretation categories of susceptibility (two isolates were sensitive in the ADM and intermediary in the Etest and two isolates were sensitive in the Etest and intermediary in the ADM).

Table 1

Comparison MIC values of ADM and Etest susceptibility of 49 B. hyodysenteriae isolates to doxycycline

\begin{tabular}{|c|c|c|c|}
\hline \multirow{2}{*}{$\begin{array}{l}\text { MIC value } \\
\text { classification } \\
\text { according to } \\
\text { NCCLS }(\mu \mathrm{g} / \mathrm{ml})\end{array}$} & \multirow{2}{*}{$\begin{array}{c}\text { Isolates proved } \\
\text { by the ADM } \\
(\%)\end{array}$} & \multicolumn{2}{|c|}{ Isolates proved by the Etest } \\
\hline & & $\begin{array}{l}\text { No. of agreeing } \\
\text { isolates }(\%)\end{array}$ & $\begin{array}{l}\text { No. of disagreeing } \\
\text { isolates }(\%)\end{array}$ \\
\hline Sensitive $(\leq 4)$ & $36 \quad(73)$ & $30 \quad(83)$ & $6 \quad(17)$ \\
\hline Intermediary (4-8) & $13 \quad(27)$ & $11 \quad(85)$ & $2(15)$ \\
\hline Resistant ( $\geq 16)$ & 0 & 0 & 0 \\
\hline Total No. & 49 & 41 (84) & $8(16)$ \\
\hline
\end{tabular}

MIC values for doxycycline obtained by the ADM and the Etest by a reference strain of B. hyodysenteriae ATCC $27164^{\mathrm{T}}$ are stated in Table 2. MIC values corresponded to NCCLS M11-A5 (2001) methodologies for anaerobic bacteria but the interpretation categories for B. hyodysenteriae were not still determined. 
MIC $_{50}$ values $(1.0 \mu \mathrm{g} / \mathrm{ml})$ and $\mathrm{MIC}_{90}$ values $(4.0 \mu \mathrm{g} / \mathrm{ml})$ for doxycycline obtained by the $\mathrm{ADM}$ and the Etest were not different.

Table 2

MICs of doxycycline for B. hyodysenteriae B78 (ATCC $27164^{\mathrm{T}}$ )

\begin{tabular}{|l|c|c|}
\hline Type strain & MIC DOX/ADM $\mu \mathrm{g} / \mathrm{ml}$ & MIC DOX/Etest $\mu \mathrm{g} / \mathrm{ml}$ \\
\hline B. hyodysenteriae ATCC $27164^{\mathrm{T}}$ & 1 & 1.5 \\
\hline
\end{tabular}

\section{Discussion}

There have been a growing number of cases of diminished efficacy of pleuromutilins diterpens (valnemulin, tiamulin) in the treatment of swine dysentery in the Czech Republic and abroad (Lobová et al. 2004). Laboratory tests have shown that this is due to an increase in the MIC values for the first choice antibiotics pleuromutilins in the treatment of $B$. hyodysenteriae isolates (Karlsson et al. 2002, 2003; Smola and Čížek 2003). To determine susceptibility of $B$. hyodysenteriae to doxycycline, the ADM was used. In most laboratories, quantitative susceptibility testing of brachyspiras is commonly done by diluting the antibacterial substance in agar media (Kitai et al. 1987; Ronne and Szancer 1990; Smith et al. 1991; Trott et al. 1996; Duhamel et al. 1998; Hommez et al. 1998; Fossi et al. 1999) or by the broth dilution method (Hayashi et al. 1988; Buller and Hampson 1994; Karlss on et al. 2002). Apart from applying the agar dilution method, which has been used by our laboratory on a daily basis for several years, a semi-quantitative method, namely the Epsilometer test for B. hyodysenteriae susceptibility to doxycycline, was analyzed. B. hyodysenteriae strains were cultivated using Wilkins-Chalgren anaerobic agar, recommended in some trials for anaerobic cultivation based on NCCLS 2001 methodologies (Rokosz et al. 2001). The MIC values obtained by the two methods agreed in $84 \%$ of the isolates (41 isolates), while $16 \%$ of the isolates had differring MIC values; most notably the isolates with low doxycycline MIC values. Regarding these notable isolates, the inconsistencies were mainly due to difficult MIC value reading, ascribable to the blurred edges of inhibitory zones. The gradient of doxycycline concentrations in the Etest was also less steep compared with the doxycycline concentrations used with the agar dilution method. Despite these inaccuracies, the Etest can still be recommended for standard performance as a suitable alternative to agar dilution method.

Similar conclusions were obtained at in an assessment of Etest suitability for determination of MIC values of antibiotics for Campylobacter jejuni strains isolated from humans. The ADM/Etest agreement was $85.5 \%$ (Oncul et al. 2003), which is in line with the results we obtained. Rosenblatt and Gustafson (1995) evaluated the Etest by determining susceptibility of anaerobic bacteria to 14 antibiotic substances and found it a suitable alternative to the agar dilution method. Similarly Midolo et al. (1997) regards the use of the Etest for strains of Helicobacter pylori, which are demanding in terms of cultivation, as a simple-to-perform method. Matsu moto et al. (1999) found the Etest to be a simple method, correlating well with the agar dilution method in terms of accuracy.

Before this practical-to-use test can be applied in a routine practice in diagnostic laboratories, inter-laboratory comparative studies will have to be performed in order to standardize the method. The inaccessibility of pleuromutilines in the Etest remains a factor limiting the method to some extent. Evaluation of MIC values for doxycycline has shown that $73 \%$ of $B$. hyodysenteriae isolates are susceptible to doxycycline while none were doxycycline-resistant. These results suggest a high number (36 isolates) of doxycyclinesusceptible isolates. Should there be $B$. hyodysenteriae strains with reduced susceptibility to pleuromutilines, doxycycline can be considered for combination therapy. An increased 
effect of tiamuline in combination with chlortetracycline has already been proved for mycoplasms and other bacterial porcine pathogens (Stipkovits 1992).

\section{Hodnocení citlivosti izolátů Brachyspira hyodysenteriae k doxycyklinu agarovou diluční metodou a Epsilometr testem}

Agar diluční metodou a Epsilometr testem byla hodnocena in vitro antibakteriální citlivost u 49 terénních kmenů Brachyspira hyodysenteriae k doxycyklinu. Porovnáním výsledků obou metod byla zjištěna shoda u $84 \%$ kmenů $B$. hyodysenteriae a u $16 \%$ kmenů se hodnoty MIC lišily o více než dvě ředění. Z celkového počtu testovaných izolátů B. hyodysenteriae bylo $36(73 \%)$ klasifikovaných jako citlivé, 13 (27\%) jako intermediární a žádný kmen nebyl k doxycyklinu rezistentní. Prokázaná citlivost izolátů $B$. hyodysenteriae k doxycyklinu naznačuje jeho možné využití k terapii dyzenterie prasat. Pro jednoduchost provedení se Epsilometr test osvědčil jako alternativa k dilučním metodám při testování citlivosti $B$. hyodysenteriae.

\section{Acknowledgements}

The study has been supported by the research project of the Veterinary Faculty of the University of Veterinary and Pharmaceutical Sciences, Brno, No. 161700001.

\section{References}

BULLER, NB, HAMPSON, DJ 1994: Antimicrobial susceptibility testing of Serpulina hyodysenteriae. Aust Vet J 71: $211-214$

ČÍŽEK, A, LOBOVÁ, D, SMOLA, J 2002: In vitro susceptibility of Brachyspira hyodysenteriae strains isolated in the Czech Republic from 1996 to 2001. In Proceedings of the 17th International Pig Veterinary Society Congress, Perry, Ames, Iowa, p. 366

ČÍŽEK, A, LOBOVÁ, D, SMOLA, J 2003: Nepříznivý vývoj ve výskytu dysenterie prasat a citlivosti kmenů Brachyspira hyodysenteriae v našich chovech. Veterinářství 53: 400

DUHAMEL, GE, KINYON, JM, MATHIESEN, MR, MURPHY, DP, WALTER, D 1998: In vitro susceptibility of North American field isolates of porcine Serpulina pilosicoli to four antimicrobials. 15th IPVS Congr. Birmingham, p.141

ELDER, RO, DUHAMEL, GE, SCHAFER, RV, MATHIESEN, MR, RAMATHAN, M 1994: Rapid detection of Serpulina hyodysenteriae in diagnostic specimens by PCR. J Clin Microbiol 32: 1497-1502

FELLSTRÖM, C, GUNNARSSON, A 1995: Phenotypical characterisation of intestinal spirochetes isolated from swine. Res Vet Sci 59: 1-4

FOSSI, M, SARANPAA, T, RAUTIAINEN, E 1999: In vitro sensitivity of the swine Brachyspira species to tiamulin in Finland 1995-1997. Acta Vet Scand 40: 355-358

HARRIS, DL, GLOCK, RD, CHRISTENSEN, CR, KINYON, JM 1972: Swine dysentery: Inoculation of pigs with Treponema hyodysenteriae (new species) and reproduction of the disease. Vet Med Small Anim Clin 67: 61-64 HAYASHI, T, SUENAGA, I, NARUKAWA, N, YAMAZAKI, T 1978: In vitro and in vivo activities of sedecamycin against Treponema hyodysenteriae. Antimicrob Agents Ch 32: 458-461

HOMMEZ, J, CASTRYCK, F, MIRY, C, LEIN, A, DEVRIESE, LA, HAESEBROUCK, F 1998: Susceptibility of different Serpulina species in pigs to antimicrobial agents. Vlaams Diergen Tijds 67: 32-35

KARLSSON, M, OXBERRY, SL, HAMPSON, DJ 2002: Antimicrobial susceptibility testing of Australian isolates of Brachyspira hyodysenteriae using a new broth dilution method. Vet Microbiol 84: 123-133

KARLSSON, M, ASPÁN, A, LANDÉN, A, FRANKLIN, A 2003: Further characterisation of Brachyspira hyodysenteriae isolates with decreased susceptibility to tiamulin. The $2^{\text {nd }}$ International Conference on Colonic Spirochaetal Infections in Animals and Humans, Scotland, abstract 22

KITAI, K, KASHIWAZAKI, M, ADACHI, Y, KUNUGITA, K, ARAKAWA, A 1987: In vitro antimicrobial activity against reference strains and field isolates of Treponema hyodysenteriae. Antimicrob Agent Ch 31: 1935-1938

LOBOVÁ, D, SMOLA, J, ČÍŽEK, A 2004: Decreased susceptibility to tiamulin and valnemulin among Czech isolates of Brachyspira hyodysenteriae. J Med Microbiol 53: 287-291

MATSUMOTO, Y, IKEMOTO, A, TAWARA, S 1999: Antibacterial activity of cefixime against Salmonella typhi and applicability of Etest. J Infect Chem 5: 176-179

MIDOLO, PD, BELL, JM, LAMBERT, JR, TURNIDGE, JD, GAYSON, ML 1997: Antimicrobial resistance testing of Helicobacter pylori: a comparison of Etest and disk diffusion methods. Pathol 29: 411-414

MOLNAR, L 1996: Sensitivity of strains of Serpulina hyodysenteriae isolated in Hungary to chemotherapeutic drugs. Vet Rec 138: 158-160 
NCCLS, 2001: Methods of antimicrobial susceptibility testing of anaerobic bacteria, Approved Standard - Fifth Edition. NCCLS document M11 - A5. Edited by NCCLS, Wayne, Pennsylvania.

ONCUL, O, ZARACOLU, P, ONCUL, O, GUR, D 2003: Antimicrobial susceptibility testing of Camphylobacter jejuni: a comparison between Etest and agar dilution method. Diagn Microbiol Infect Dis 45: 69-71

ROKOSZ, A, SAWICKA-GRZELAK, A, KOT, K, MESZAROZ, J, LUCZAK, M 2001: Use of the Etest method for antimicrobial susceptibility testing of obligate anaerobes. Med Dosw Microbiol 53: 167-175

RONNE, H, SZANCER, J 1990: In vitro susceptibility of Danish field isolates of Treponema hyodysenteriae to chemoterapeutics in swine dysentery therapy. Proc. IPVS 11th Congr Lausanne, p. 196

ROSENBLATT, JE, GUSTAFSON, DR 1995: Evaluation of the Etest for susceptibility testing of anaerobic bacteria. Diagn Microbiol Infect Dis 22: 279-284

SMITH, SC, MIUR, T, HOLMES, M, COLOE, PJ 1991: In vitro antimicrobial suspectibility of Australian isolates of Treponema hyodysenteriae. Austr Vet J 68: 408-409

SMOLA, J, ČÍŽEK, A 2003: Antimicrobial agents for colonic spirochaetal infections. The $2^{\text {nd }}$ International Conference on Colonic Spirochaetal Infections in Animals and Humans, Scotland, abstract 21

STIPKOVITS, L 1992: Enhancement effect of tiamulin hydrogen fumarate + chlortetracycline combination on mycoplasmas and some bacteria in-vitro and in-vivo, Papers on tiamulin presented at the $12^{\text {th }}$ IPVS Congress, the Hague, Netherlands and the tetramutin seminar, pp. 86-94

TROTT, DJ, STANTON, TB, JENSEN, NS, DUHAMEL, GE, JOHNSON, JL, HAMPSON, DJ 1996: Serpulina pilosicoli sp.nov., the agent of porcine intestinal spirochetosis. Int J Syst Bact 46: 206-215 